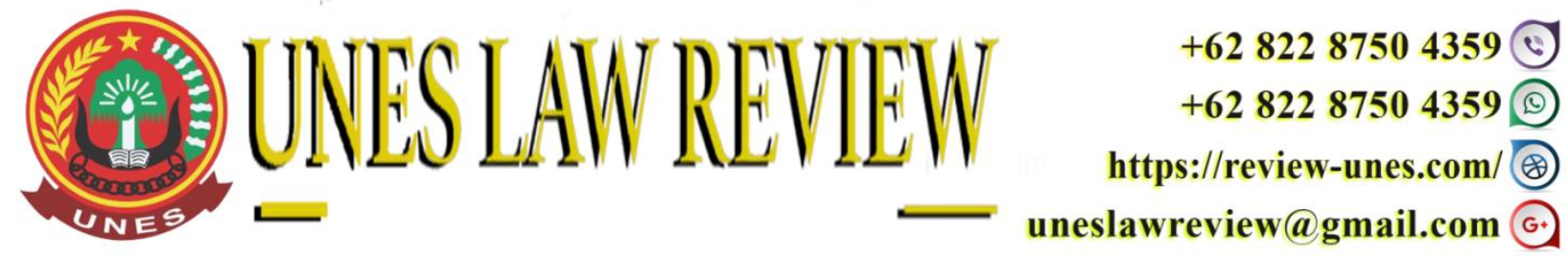

DOI: https://doi.org/10.31933/unesrev.v3i3

Diterima: 14/01/2021, Diperbaiki: 14/02/2021, Diterbitkan: 07/03/2021

\title{
PENCEGAHAN POLITIK UANG PADA PEMILIHAN KEPALA DAERAH OLEH BADAN PENGAWAS PEMILU KABUPATEN SOLOK
}

\section{Dedi Indriadi}

Program Magister Ilmu Hukum, Universitas Ekasakti, Padang, Indonesia

Email: dedibatubara101@gmail.com

Corresponding Author: Dedi

\section{ABSTRACT}

Regional head elections are often colored by the practice of money politics carried out by regional head candidates in connection with the above matter. Bawaslu of Solok district as the organizer of the regional head election is tasked with overseeing the stages of holding regional head elections, one of which is to anticipate the occurrence of money politics. The efforts of the Election Supervisory Agency for Solok Regency in Preventing Money Politics in Regional Head Elections are pre-Emtive efforts by appealing to all candidate pairs not to commit money politics crimes. Preventive efforts are in the form of limiting campaign activities, using informants in Nagari, holding counseling and socialization and then taking action to take action. Obstacles to the Election Supervisory Body for the Election of Solok Regency in Efforts to Prevent Money Politics in the Regional Head Election is that there are regulations regarding elections and campaigns only conducted during the election and campaign period, whereas in fact many prospective candidates engage in money politics before the campaign period.

Keywords: Money Politics, Prevention, Bawaslu

\begin{abstract}
ABSTRAK
Pada pemilihan kepala derah seringkali diwarnai dengan praktek politik uang yang dilakukan oleh calon kepala daerah berkaitan dengan hal tersebut diatas Bawaslu kabupaten Solok sebagai penyelenggara pemilihan kepala daerah bertugas mengawasi tahap tahap penyelenggaraan pemilihan kepala daerah yang salah satunya adalah mengantisipasi terjadinya politik uang. Upaya Badan Pengawas Pemilu Kabupaten Solok Dalam Pencegahan Politik Uang Pada Pemilihan Kepala Daerah adalah dengan upaya Pre-Emtif dengan cara melakukan himbauan kepada seluruh pasangan calon agar tidak melakukan tindak pidana politik uang (Money politic). Upaya preventif berbentuk Membatasi kegiatan kampanye, Menggunakan informan di Nagari, mengadakan penyuluhan dan sosialisasi dan Selanjutnya adalah upaya melakukan penindakan. Kendala Badan Pengawas Pemilu Kabupaten Solok Dalam Upaya Pencegahan Politik Uang Pada Pemilihan Kepala daerah adalah adanya peraturan mengenai pemilu dan kampanye hanya
\end{abstract}


dilakukan pada masa pemilu dan kampanye sedangkan kenyataannya banyak bakal calon yang melakukan politik uang sebelum masa kampanye.

Kata Kunci: Politik Uang, Pencegahan, Bawaslu

\section{PENDAHULUAN}

Sistem politik dan penyelenggaraan kekuasaan negara yang bertujuan mencapai cita negara hukum dan konstitusionalisme di Indonesia mengalami perubahan besar pasca amandemen Undang-undang Dasar Negara Republik Indonesia Tahun 1945 (UUD NRI 1945). Hal ini dipertegas dalam UUD NRI 1945 yang menyatakan Negara Indonesia adalah negara hukum dan negara yang menganut prinsip demokrasi. Sebagai perwujudan demokrasi, dalam International Commisision of Jurist, Bangkok Tahun 1965 dirumuskan bahwa penyelenggaraan pemilihan umum (Pemilu) yang bebas merupakan salah satu syarat dari enam syarat dasar bagi negara demokrasi di bawah rule of law.

Politik uang pada pemilihan kepala daerah diatur dalam Undang-Undang Republik Indonesia Nomor 10 Tahun 2016 Tentang Perubahan Kedua Atas Undang-Undang Nomor 1 Tahun 2015 Tentang Penetapan Peraturan Pemerintah Pengganti Undang-Undang Nomor 1 Tahun 2014 Tentang Pemilihan Gubernur, Bupati, Dan Walikota Menjadi Undang-Undang pada Pasal 187A (1).

Untuk penegakan hukum pada pelanggaran Pemilu, salah satunya politik uang dibentuk Badan Pengawas Pemilu. Pengawasan pemilu secara teknis diatur dalam pasal 1 angka 23 Peraturan Bawaslu Nomor 13 Tahun 2012 tentang Tata Cara Pengawasan Pemilu dikonsepsikan sebagai kegiatan mengamati, mengkaji, memeriksa, dan menilai proses penyelenggaraan Pemilu sesuai peraturan perundang-undangan. Bawaslu berkewajiban bersikap tidak diskriminatif dalam menjalankan tugas dan wewenangnya serta melakukan pembinaan dan pengawasan terhadap pelaksanaan tugas Pengawas Pemilu pada semua tingkatan.

Adapun bentuk politik uang pada prakteknya di masyarakat yaitu dengan pemberian uang atau pemberian barang yang diberikan beragam mulai dari alat rumah tangga, bahan bakar, bahan bangunan, bahan elektronik, kitab suci hingga makanan dan sembako. Praktek politik uang tidak hanya dilakukan pada masa kampanye tetapi juga pada masa tenang. Dalam sistem Pemilu secara langsung tahun sebelum ini yang membuka maraknya praktek politik uang di Kabuapten Solok, dalam situasi yang serba sulit seperti saat ini, uang merupakan alat kampanye yang cukup ampuh untuk mempengaruhi masyarakat guna memilih calon kepala daerah tertentu.

Pada tahun 2020 ini pemilihan kepala daerah secara serentak diselenggarakan pada tanggal 9 Desember 2020 dimana Kabupaten Solok termasuk salah satu Kabupaten yang akan menyelenggarakan pemilihan kepala daerah . Berdasarkan penetapan KPU Kabupaten Solok pasangan calon yang menjadi kontestasi bupati dan Wakil Bupati ada 8 calon. Politik uang dikategorikan sebagai masalah serius dalam Pemilu Kepala Daerah. Berkaitan dengan hal di atas Bawaslu Kabupaten Solok Periode 2019-2024 telah melakukan kegiatan kegiatan dalam rangka mengantisipasi dan mencegah terjadinya politik uang dalam tahapan pemilihan kepala daerah. 
Berdasarkan latar belakang yang dipaparkan di atas, maka permasalahan yang dibahas adalah upaya dan kendala badan pengawas pemilu kabupaten solok dalam pencegahan politik uang pada pemilihan kepala daerah.

\section{METODE PENELITIAN}

Spesifikasi penelitian adalah deskriptif analitis, dengan metode pendekatan yuridis normatif didukung yuridis empiris. Jenis data yang digunakan adalah data sekunder dan data primer. Data sekunder diperoleh dari studi dokumen dan studi kepustakaan. Data yang diperoleh kemudian dianalisa secara kualitatif .

\section{HASIL DAN PEMBAHASAN}

\section{Upaya Badan Pengawas Pemilu Kabupaten Solok Dalam Pencegahan Politik Uang Pada Pemilihan Kepala Daerah}

Upaya penanggulangan adalah usaha, ikhtiar guna mencapai suatu maksud dengan proses untuk menanggulangi suatu kejahatan dalam hal ini adalah politik uang (Money politic). Upaya penanggulangan kejahatan yang dikemukakan oleh Arif Barda Nawawi di atas memperlihatkan bahwa dalam rangka penanggulangan tindak pidana atau kejahatan maka 3 (Tiga) sifat upaya yaitu upaya awal mencegah terjadinya tindak pidana (pre-emtif), penanggulangan sebelum terjadinya kejahatan (preventif) dan, upaya penanggulangan setelah terjadinya kejahatan (represif).

Adapun bentuk upaya penanggulangan politik uang pada masa pemilihan kepala daerah yang dilakukan oleh Bawaslu kabupaten Solok adalah berbentuk Upaya Pre-Emtif. Berdasarkan hasil wawancara dengan Petugas Bawaslu Kabupaten Solok bahwa Upaya Penanggulangan Politik Uang (Money politic) Pada Tahap Persiapan Dan Pelaksanaan Pilkada Serentak Di Kabupaten Solok dalam bentuk PreEmtif yang telah di implementasikan oleh Badan Pengawas Pemilihan Umum Kabupaten Solok antara lain: ketika KPU (Komisi Pemilihan Umum) Kabupaten Solok dalam masa sebelum penetapan calon peserta pemilu maka bawaslu melakukan himbauan kepada seluruh pasangan calon agar tidak melakukan tindak pidana politik uang (Money politic) karena konsekuensi dari melakukan Politik Uang adalah beresiko dapat dibatalkan sebagai calon kalau ada keputusan pengadilan yang inkrah

Dalam upaya penanggulangan PreEmtif semua aspek harus turut ikut serta dalam mencegah adanya kesempatan, contoh nya masyarakat harus cerdas di dalam kampanye seorang calon, jika calon tersebut bagi-bagi sembako kepada masyarakat maka sebagai masyarakat jangan langsung di terima sembako tersebut tanyakan tujuan dan niat dari pasangan calon tersebut terlebih dahulu. Jika masyarakat sudah menolak sembako dari pasangan calon tersebut maka otomatis niat pasangan calon untuk melakukan politik uang (Money politic) jadi hilang. Menurut Narasumber upaya penanggulangan Pre-Emtif adalah upaya yang menghilangkan niat dan kesempatan bagi calon yang ingin melakukan politik uang (Money politic)

Selanjutnya adalah upaya yang berbentuk Preventif berupa pencegahan terjadinya politik uang. Penanggulangan tindak pidana politik uang (Money politic) dilakukan untuk mencegah terjadinya atau timbulnya tindak pidana yang pertama kali. Mencegah terjadinya tindak pidana 
lebih baik daripada mencoba untuk mendidik pelaku tindak pidana untuk menjadi lebih baik kembali, sebagaimana semboyan dalam kriminologi yaitu usaha-usaha memperbaiki pelaku tindak pidana perlu diperhatikan dan diarahkan agar tidak terjadi kejahatan ulang. Sangat beralasan upaya preventif diutamakan karena upaya preventif dapat dilakukan oleh siapa saja tanpa suatu keahlian khusus dan ekonomis. Upaya preventif menduduki posisi kunci dan strategis dari seluruh upaya politik kriminil. Upaya preventif ini adalah untuk memperbaiki kondisi-kondisi social tertentu. Dengan demikian dilihat dari sudut kriminal, Seluruh kegiatan preventif melalui upaya itu mempunyai kedudukan strategis, memegang posisi kunci yang harus diintensifikasikan dan diefektifkan.

Badan Pengawas Pemilu dalam menanggulangi politik uang (Money politic) harus jemput bola (Memasang Orang-orang) tidak hanya mengandalkan diri sendiri karena Badan Pengawas Pemilu memiliki keterbatasan tenaga dan keterbatasan kemampuan oleh karena keterbatasan itu rentan dengan politik uang (Money politic), yang di maksud memasang orang-orang ialah Badan Pengawas Pemilu memasang kaki tangan di sebuah desa, kaki tangan dari Badan Pengawas Pemilu harus orang asli dari Nagari sana karena jika dari anggota resmi dari Badan Pengawas Pemilu yang menjadi kaki tangan maka sudah dicurigai, tetapi jika penduduk asli tersebut maka tidak dicurigai karena orang tersebut memang penduduk asli nagari sana sehingga tidak menimbulkan kecurigaan padahal sebenarnya orang itu adalah kaki tangan Badan Pengawas Pemilu, karena menurutnya pasangan calon yang berani melakukan tindakan tindak pidana politik uang (Money politic) karena mereka beranggapan tidak ada yang mengawasi, jika yang mengawasi adalah orang yang tidak di sangkasangka maka tindak pidana politik uang (Money politic) dapat ditanggulangi karena calon yang ingin melakukan politik uang akan was-was terhadap orang disekitarnya dan calon pasangan tersebut ragu untuk melakukan tindak pidana politik uang (Money politic).

Badan Pengawas Pemilu dalam menanggulangi tindak pidana politik uang (Money politic) melakukan sosialisasi-sosialisasi yang berkaitan dengan pencegahan pelanggaran pemilu, varian sosalisasi ada dengan cara tatap muka dengan masyarakat, dengan Stakeholder yang berterkaitan dengan Pemilu mulai dari instansi instansi terkait, kelembagaan kelembagaan, Ormas/ LSM. Sedangkan di tingkat pusat Badan Pengawas Pemilu memiliki MoU (Memorandum of Understanding) / Nota kesepakatan dengan PPATK (Pusat Pelaporan dan Analisis Transaksi Keuangan) pada aspek hulu, sedangkan aspek hilir di daerah.

\section{Kendala Badan Pengawas Pemilu Kabupaten Solok Dalam Upaya Pencegahan Politik Uang Pada Pemilihan Kepala Daerah}

Faktor penghambat dalam penegakan hukum pidana menurut teori yang dilakukan oleh Soejono Soekanto yang menyebutkan faktor-faktor yang mempengaruhi adalah diantaranya faktor Undang-Undang menpunyai peran yang utama dalam penegakan hukum dan berlakunya kaedah hukum dimasyarakat ditinjau dari kaedah hukum itu sendiri. Seharusnya peraturan mengenai pemilu dan kampanye harus dievaluasi terutama pada masa sebelum penetapan menurut penulis kegiatan membagibagikan tersebut dapat menguntungkan bakal calon tersebut 
sehingga bakal calon yang memiliki uang lebih memiliki kesempatan menang lebih besar dari pada bakal calon yang tidak melakukan kegitan membagi-bagikan tersebut.

Faktor ini adalah salah satu faktor penting pada penegakan hukum, karena penegak hukum merupakan aparat yang melaksanakan proses upaya untuk tegaknya atau berfungsinya norma norma hukum secara nyata sebagai pedoman perilaku hubungan-hubungan hukum dalam kehidupan bermasyarakat dan bernegara, untuk menjamin dan memastikan tegaknya hukum itu sendiri.

Kepolisian dan sentra gakkumdu adalah aparat penegak hukum, jika ada pelanggaran politik uang (Money politic) perlu dilakukan pelaporan maka di dalam penanganan pelaporan itu di atur di dalam pasal 134 ayat 1,2 dan 3. Kurangnya syarat pelaporan merupakan salah satu faktor penghambat kepolisian dan sentra gakkumdu dalam upaya penanggulangan politik uang (Money politic).

Faktor sarana atau fasilitas pendukung mencakup perangkat atau fasilitas pendukung mencakup perangkat lunak dan perangkat keras. Sarana dan fasilitas yang memadai diperlukan demi mendukung proses penanggulangan politik uang, dalam mendukung proses penanggulangan politik uang diperlukan sarana dan fasilitas pengaduan masyarakat yang mudah untuk mengadukan kegiatan politik uang karena jika sarana dan fasilitas pengaduan kurang maka itu menjadi salah satu faktor penghambat untuk menanggulangi politik uang, karena jika fasilitas dan sarana kurang memadai, maka upaya penanggulangan akan terhambat.

Kepatuhan hukum masyarakat terhadap hukum, merupakan salah satu indikator berfungsinya hukum yang bersangkutan. Sikap masyarakat yang kurang menyadari bahwa setiap warga turut serta dalam penegakan hukum tidak semata-mata menganggap tugas penegakan hukum urusan penegak hukum menjadi salah satu faktor penghambat dalam penegakan hukum. Seharusnya prilaku masyarakat harus ditingkatkan, karena prilaku yang baik berperan penting untuk mencegah terjadinya politik uang (Money politic), prilaku yang baik masyarakat seharusnya sudah diberikan sejak masa pendidikan, jadi pada saat proses pendidikan prilaku yang baik sudah terbentuk di dalam masyarakat. Maka jika prilaku masyarakat sudah baik, jika calon melakukan politik uang maka masyarakat tidak menerimanya akan tetapi masyarakat melaporkan tindakan tersebut pada aparat penegak hukum yaitu pihak yang berwajib.

Kebudayaan Indonesia merupakan dasar dari berlakunya hukum adat. Berlakunya hukum tertulis (perundang-undangan) harus mencerminkan nilainilai yang menjadi dasar hukum adat. Dalam penegak hukum, semakin banyak penyesuaian antara peraturan perundang-undangan dengan kebudayaan masyarakat. Budaya masyarakat dan lemahnya ekonomi masyarakat maka banyak masyarakat yang ingin mengambil uang atau materi dari calon pasangan yang melakukan politik uang bukanya melaporkan tindakan tersebut ini menjadi salah satu faktor penghambatnya. Karena banyaknya masyarakat mengambil uang atau materi dari calon pasangan yang melakukan politik bukanya melaporkan tindakan tersebut maka ini yang membuat semakin banyak pula pasangan calon yang melakukan politik uang.

Berdasarkan uraian di atas maka penulis menganalisis bahwa faktor yang paling dominan di faktor penghambat ialah faktor Perundang undangan karena di dalam undang undang 
mengenai pilkada masih banyak celah yang rentan untuk dilakukannya politik uang (Money politic) salah satunya adalah pada saat sebelum penetapan. Undang-Undang mengenai politik uang (Money politic) sebelum masa penetapan memang masih belum di atur, jika pasangan calon tersebut belum ditetapkan maka pasangan tersebut belum ada keterikatan dengan Komisi Pemilihan Umum. Karena sebelum masa penetapan pasangan calon tersebut bukan siapa-siapa jadi sebelum masa penetapan Komisi Pemilihan Umum kesulitan dalam melakukan tindakan karena kebanyakan dari bakal calon tersebut berdalih mereka melakukan sedekah bukan politik uang (Money politic). Calon tersebut beranggapan jika melakukan sedekah tidak mungkin dilarang karena mereka belum ada keterikatan dengan Komisi Pemilihan Umum. Menurut penulis seharusnya peraturan mengenai pemilu dan kampanye harus dievaluasi terutama pada masa sebelum penetapan menurut penulis kegiatan membagi-bagikan tersebut dapat menguntungkan bakal calon tersebut sehingga bakal calon yang memiliki uang lebih memiliki kesempatan menang lebih besar dari pada bakal calon yang tidak melakukan kegitan membagibagikan tersebut.

\section{PENUTUP}

Upaya Badan Pengawas Pemilu Kabupaten Solok Dalam Pencegahan Politik Uang Pada Pemilihan Kepala Daerah adalah dengan upaya Pre-Emtif dengan cara ketika KPU (Komisi Pemilihan Umum) Kabupaten Solok dalam masa sebelum penetapan calon peserta pemilu maka bawaslu melakukan himbauan kepada seluruh pasangan calon agar tidak melakukan tindak pidana politik uang (Money politic) karena konsekuensi dari melakukan Politik Uang adalah beresiko dapat dibatalkan sebagai calon kalau ada keputusan pengadilan yang inkrah. Upaya preventif berbentuk Membatasi kegiatan kampanye, Menggunakan informan di Nagari, mengadakan penyuluhan dan sosialisasi dan Selanjutnya adalah upaya melakukan penindakan berupa proses hukum pidana bagi yang terbukti melakukan tindak pidana suap berbentuk politik uang.

Kendala Badan Pengawas Pemilu Kabupaten Solok Dalam Upaya Pencegahan Politik Uang Pada Pemilihan Kepala daerah adalah adanya peraturan mengenai pemilu dan kampanye hanya dilakukan pada masa pemilu dan kampanye sedangkan kenyataannya banyak bakal calon yang melakukan politik uang sebelum masa kampanye. Kurangnya syarat pelaporan merupakan salah satu faktor penghambat kepolisian dan sentra gakkumdu dalam upaya penanggulangan politik uang (Money politic). Sikap masyarakat yang kurang menyadari bahwa poltik uang adalah perbuatan melanggar hukum, sehingga masyarakat seharusnya tidak menerima pemberian tersebut begitu saja akan tetapi masyarakat melaporkan tindakan tersebut pada aparat penegak hukum yaitu pihak yang berwajib. Budaya masyarakat dan lemahnya ekonomi masyarakat maka banyak masyarakat yang ingin mengambil uang atau materi dari calon pasangan yang melakukan politik uang bukanya melaporkan tindakan tersebut 


\section{DAFTAR PUSTAKA}

Abdul Bari Azed, Sistem-Sistem Pemilihan Umum, Badan Penerbit Fakultas Hukum Universitas Indonesia, UI Depok, Jakarta, 2000

Barda Nawawi Arief, Kebijakan Hukum Pidana, Bandung: Citra Aditya Bakti, 2002, hlm. 68 